\title{
In-vivo protein quality assessment of macerated African elemi pulp eaten as masticatories in Eastern Nigeria
}

\author{
E. A. A. Anyalogbu ${ }^{1 *}\left(\mathbb{D}\right.$, E. N. Onyeike ${ }^{2}$ and P. C. Nweje-Anyalowu ${ }^{3}$
}

\begin{abstract}
Background: The ability of a protein to accomplish distinct metabolic actions depends on its balance of amino acids, the digestibility to release the amino acids for absorption, and the availability of the absorbed amino acids for protein synthesis. In this study, this mark of protein quality was evaluated in vivo for macerated African elemi pulp eaten as masticatory in eastern Nigeria by assessing the effect of its inclusion in diets relative to reference diets on protein quality indices of growing albino rats sustained on the diets.
\end{abstract}

Method: Samples obtained from Aba, Abia State, Nigeria, were portioned into four, processed by subjecting them to $0,15,30$, and 45 min heat contact times in water $\left(55^{\circ} \mathrm{C}\right)$, and labeled $A E_{0}, A E_{15}, A E_{30}$, and $A E_{45}$ respectively. Diets formulated using the samples, giving approximately $10 \%$ protein, together with reference (Nutrend ${ }^{\circledR}$ ) and basal diets were offered ad libitum to weaning albino rats for a 28-day feeding period. The growth performance parameters and in vivo protein quality indices of the rats were assessed using standard procedures.

Results: Processing improved feed utilization (FU), feed conversion ratio (FCR), protein efficiency ratio (PER) and, except at $\mathrm{AE}_{30}$, net protein utilization (NPU) and biological value (BV) of the rats. The PER was above 2.0 in all the rats sustained on test sample diets given the range $2.03 \pm 0.23$ to $2.28 \pm 0.35$. The fecal nitrogen (FN), carcass weight (CW), true digestibility (TD), and BV were statistically similar ( $\left.p^{>} 0.05\right)$ in rats fed both samples and reference diets with BV being above $70 \%$. Relative to FN, TD, and BV, this statistical parity between animals on test and reference diets could suggest adequacy of the digestibility of the proteins of the sample diets and the similarities in their qualities.

Conclusion: The plant food, African elemi drupe pulp, could therefore be metabolically adjudged rich in highquality protein that is capable of supporting human growth and tissue maintenance.

Keywords: Biological value, Protein efficiency ratio, True digestibility, Fecal nitrogen, Canarium schweinfurthii

\section{Introduction}

The usefulness of a protein product depends on the extent the protein source is able to meet biological needs (Moore and Soeters 2015). This, according to "The United Nations University" publication (1980), is predicated on both the quantity of the protein in the product and its nutritive quality. Protein quality, as stated by Millward et al. (2008), implies the features of a protein that enables it to accomplish distinct metabolic actions

\footnotetext{
* Correspondence: aaenweje@gmail.com

'Department of Biotechnology, School of Biological Science, Federal

University of Technology Owerri, Imo State, Owerri, Nigeria

Full list of author information is available at the end of the article
}

which according to Pencharz et al. (2016) depends on the protein's balance of the amino acids, the digestibility of the protein to release the amino acids for absorption, and the availability of the absorbed amino acids for protein synthesis. Based on the fact that the function of dietary protein is to provide the 20 amino acids for which tRNA exists (Pencharz et al. 2016), the amino acid score could be used to assess the quality of some proteins, while others cannot because of poor digestibility and/or bioavailability. The capacity of this latter group and of protein generally to promote animal growth in vivo has been used as the metabolic indicator of their quality. Growth in young animal is a measure of protein 
efficiency ratio in which biological value (i.e., digestibility and balanced amino acid pattern) of absorbed amino acids defines the net protein utilization which underlines the capacity of the protein to provide metabolically available nitrogen and amino acid to tissues and organs (Millward et al. 2008). African elemi (Canarium schweinfurthii), also known as bush candle (English), Ube mgba (Igbo), Origbo (Yoruba), and Atili (Hausa), is an ever green Burseraceae tree native to Central and West Africa (Anyalogbu et al. 2014). The plant bears fruit, a drupe (Plate 1) that is macerated and the pulp eaten as masticatory in most parts of Nigeria. This work is therefore intended to evaluate the metabolic protein quality of this African elemi drupe pulp by assessing the effect of its inclusion in diets relative to reference diets on protein quality indices of growing albino rats sustained on the diets.

\section{Materials and methods}

\section{Sample collection and processing}

Thirty weanling albino rats (Rattus norvegicus) aged between 21 and 30 days and weighing between $26.17 \mathrm{~g}$ and $71.0 \mathrm{~g}$ were procured from the Department of Animal Health and Production, Faculty of Veterinary Medicine, University of Nigeria, Nsukka. Fruits of African elemi were obtained from Ngwa road market Aba, Aba South Local Government Area, Abia State, Nigeria. The fruits were processed as described by Anyalogbu et al. (2014). The researchers stated that best eaten tenderness of the pulp was achieved by macerating the fruits for $30 \mathrm{~min}$ in water $\left(55^{\circ} \mathrm{C}\right)$. The raw pulp and ones macerated for 15 , 30 , and $45 \mathrm{~min}$ in water $\left(55^{\circ} \mathrm{C}\right)$ were labeled $\mathrm{AE}_{0}, \mathrm{AE}_{15}$, $\mathrm{AE}_{30}$, and $\mathrm{AE}_{45}$ respectively.

\section{Formulation of the experimental diets}

The flours of $\mathrm{AE}_{0}, \mathrm{AE}_{15}, \mathrm{AE}_{30}$, and $\mathrm{AE}_{45}$ based on protein contents (g/100 g sample) of $14.60 \pm 0.51,13.20 \pm 1.00$, $12.59 \pm 0.87$, and $12.56 \pm 1.10$, respectively reported by Anyalogbu et al. (2014), were used in formulating feed for the experimental animals as shown in Table 1. The samples were added in the diets at the expense of corn starch (with basal protein content of $4.0 \mathrm{~g} / 100 \mathrm{~g}$ sample) giving

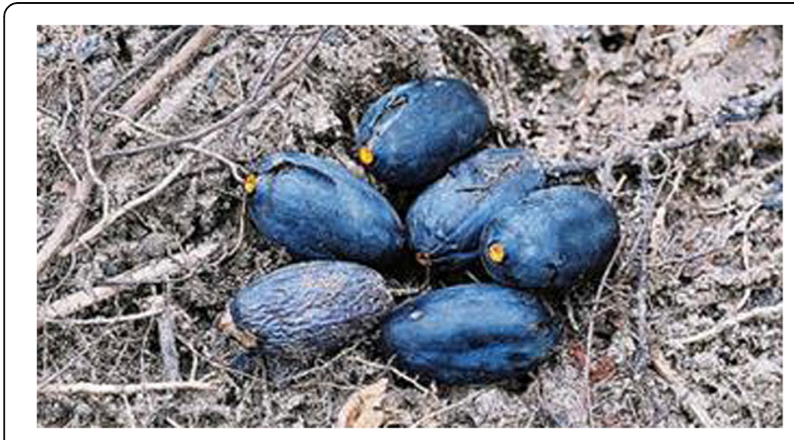

Plate 1 African elemi fruits (Anyalogbu et al. 2014)
Table 1 Composition of formulated diets $(\mathrm{g} / \mathrm{kg})$

\begin{tabular}{lllllll}
\hline \multirow{2}{*}{ Components (g) } & \multicolumn{7}{l}{ Diets } & & & & \\
\cline { 2 - 7 } & $\mathrm{AE}_{0}$ & $\mathrm{AE}_{15}$ & $\mathrm{AE}_{30}$ & $\mathrm{AE}_{45}$ & $\mathrm{NCD}$ & $\mathrm{RD}$ \\
\hline Sample & 654 & 757 & 794 & 796 & - & - \\
Sucrose & 113 & 113 & 113 & 113 & 113 & - \\
Red palm oil & 5 & 5 & 5 & 5 & 5 & - \\
Vitamin and mineral mix & 25 & 25 & 25 & 25 & 25 & - \\
Non-nutritive cellulose & 25 & 25 & 25 & 25 & 25 & - \\
a Nutrend & - & - & - & - & - & 1000 \\
Corn flour & 178 & 75 & 38 & 36 & 837 & - \\
Total (kg) & 1.0 & 1.0 & 1.0 & 1.0 & 1.0 & 1.0 \\
\hline
\end{tabular}

$N C D$ negative control diet, $R D$ reference diet; ${ }^{\mathrm{a}} \mathrm{A}$ commercial infant formula

approximately the conventional $10 \%$ dietary protein (The United Nations University 1980). Other ingredients used in formulating the diets were added as indicated in the table to impart specific qualities to the diets. Corn flour and Nutrend ${ }^{\circ}$ (a commercial infant formula) were used as basal/negative control (NC) and positive control/reference diets (RD) respectively. The calculated proximate composition and energy values of the formulated diets are given in Table 2.

\section{Experimental design}

The thirty weanling albino rats used were divided into six groups of five rats each based on initial weights such that the groups initial mean weights were as nearly as possible equalized (Anyalogbu and Onyeike 2018). The groups were labelled $\mathrm{AE}_{0}, \mathrm{AE}_{15}, \mathrm{AE}_{30}, \mathrm{AE}_{45}, \mathrm{NCD}$, and RD. Members of each group were housed individually in wire cages with raise platform to enable collection of spilt feeds and feces. For a 28-day period after acclimatization, water and specific diets were offered ad libitum to the rats. Then, the animals were subjected to 6-h fast, their weights (final weights) taken, and euthanized by exposure to chloroform in a closed container. Spilt feed and droppings of each rat were dried and weighed.

\section{Protein quality parameters}

As described by Anyalogbu and Onyeike (2018), body weight change (BWC), feed intake (FI), and hence protein intake (PI) which describes the amount of feed voluntarily consumed by an animal were calculated and fecal and carcass $\mathrm{N}_{2}$ determined using Kjeldahl method. Other protein quality parameters were calculated as explained by the authors using the stated formulas:

Feed utilization (FU):

$$
F U=\frac{\text { Weight gain }(\mathrm{mg})}{\text { Quantity of dried feed consumed }(\mathrm{g})}
$$

Feed conversion ratio (FCR): 
Table 2 Proximate composition and energy values of experimental diets

\begin{tabular}{llllll}
\hline Diet & \multicolumn{5}{l}{ Nutrient composition (g/100 g)/energy value (Kcal/100 g sample) } \\
\cline { 2 - 6 } & Protein & Fat & Carbohydrate & Energy value (Kcal/100 g sample) & Protein-energy ratio \\
\hline $\mathrm{AE}_{0}$ & 10.30 & 28.36 & 49.92 & 496.68 & 0.02 \\
$\mathrm{AE}_{15}$ & 10.35 & 32.76 & 42.73 & 507.24 & 0.02 \\
$\mathrm{AE}_{30}$ & 10.16 & 33.61 & 42.35 & 512.65 & 0.02 \\
$\mathrm{AE}_{45}$ & 10.15 & 34.60 & 40.94 & 515.88 & 0.02 \\
$\mathrm{NCD}$ & 4.19 & 0.50 & 94.0 & 401.26 & 0.01 \\
$\mathrm{RD}$ & 15.0 & 9.0 & 64.2 & 397.80 & 0.04 \\
\hline
\end{tabular}

$N C D$ negative control diet, $R D$ reference diet

$$
\mathrm{FCR}=\frac{\text { Bodyweight gain }(\mathrm{g})}{\text { Quantity of dried feed consumed }(\mathrm{g})} \quad \mathrm{BV}=\frac{\mathrm{NPU}}{\mathrm{TD}} \times 100
$$

Protein efficiency ratio (PER):

$$
\text { PER }=\frac{\text { Weight }(\mathrm{g})(\text { gain } / \text { loss }) \text { at the end of the feeding period }}{\text { Weight }(\mathrm{g}) \text { of protein consumed }}
$$

Net protein utilization (NPU):

$$
\mathrm{NPU}=\frac{B-(\mathrm{Bk}-\mathrm{Ik}) \times 100}{I}
$$

where $B$ and $B k$ were the carcass nitrogen of animals on the test and basal diets respectively while $I$ and Ik were the intake of nitrogen in the two rat groups.

Apparent (protein) digestibility (AD):

$$
A D(\%)=\frac{N \text { intake }(\mathrm{g})-\text { fecal } N(\mathrm{~g})}{N \text { intake }(\mathrm{g})} \times \frac{100}{1}
$$

True (protein) digestibility (TD):

$$
\mathrm{TD}(\%)=\frac{I-(F-\mathrm{Fk}) \times 100}{I}
$$

where $F$ and Fk were the fecal $\mathrm{N}_{2}$ of animals on the protein and basal diets respectively, and $I$ is the $\mathrm{N}_{2}$ intake of animals on the protein diets.

Biological value (BV):

\section{Statistical analyses}

Data generated were analyzed using one-way analysis of variance (ANOVA) and treatment means (expressed as means \pm SDs) compared by Duncan's multiple range tests using Statistical Package for Social Sciences (SPSS) version 20. Significance was accepted at 5\% level ( $p \leq$ 0.05 ) or $95 \%$ confidence limit.

\section{Results}

Performance characteristics of rat groups respectively fed diets compounded with African elemi seed pulp flours as protein $(10 \%)$ sources and, negative control and reference diets are presented in Table 3 . The growth performance parameters (BWC, FI, NI, PI, FU, and FCR) of rats fed diet based on African elemi seed pulp subjected to various maceration times were significantly $\left(p^{<} 0.05\right)$ higher than those fed protein-free diet but lower than those fed reference diet (Nutrend ${ }^{\circ}$ ).

On the other hand, the corresponding in vivo protein quality indices $(\mathrm{CN}, \mathrm{FN}, \mathrm{CW}, \mathrm{FDW}, \mathrm{PER}, \mathrm{NPU}, \mathrm{AD}, \mathrm{TD}$, and BV) are presented in Table 4. The FN, CW, TD,

\begin{tabular}{|c|c|c|c|c|c|c|}
\hline \multirow[t]{2}{*}{ Performance parameter } & \multicolumn{6}{|l|}{ Diet } \\
\hline & $\overline{\mathrm{AE}_{0}}$ & $\mathrm{AE}_{15}$ & $A E_{30}$ & $\mathrm{AE}_{45}$ & NCD & $\mathrm{RD}$ \\
\hline Body weight change (g) (BWC) & $54.49 \pm 3.87^{c}$ & $53.79 \pm 1.74^{c}$ & $57.20 \pm 13.76^{c}$ & $64.04 \pm 10.77^{c}$ & $8.17 \pm 1.62^{\mathrm{a}}$ & $116.86 \pm 24.45^{b}$ \\
\hline Feed intake (g) (FI) & $259.17 \pm 26.71^{d}$ & $239.0 \pm 3.46^{c}$ & $261.58 \pm 8.93^{d}$ & $267.33 \pm 11.86^{\mathrm{d}}$ & $176.17 \pm 5.11^{\mathrm{a}}$ & $291.17 \pm 18.25^{b}$ \\
\hline Nitrogen intake $(\mathrm{g})(\mathrm{NI})$ & $4.22 \pm 0.44^{\mathrm{cd}}$ & $3.67 \pm 0.06^{c}$ & $4.27 \pm 0.14^{\mathrm{cd}}$ & $4.47 \pm 0.20^{d}$ & $1.18 \pm 0.03^{\mathrm{a}}$ & $6.95 \pm 0.45^{\mathrm{b}}$ \\
\hline Protein intake (g) (PI) & $26.40 \pm 2.74^{c d}$ & $24.79 \pm 0.36^{c}$ & $26.67 \pm 0.90^{c d}$ & $27.94 \pm 1.23^{d}$ & $7.39 \pm 0.21^{a}$ & $43.50 \pm 2.94^{b}$ \\
\hline Feed utilization (mg/g) (FU) & $210.23 \pm 22.06^{c}$ & $225.03 \pm 5.36^{c}$ & $218.64 \pm 46.09^{c}$ & $239.57 \pm 35.89^{c}$ & $46.43 \pm 9.99^{\mathrm{a}}$ & $401.14 \pm 57.18^{b}$ \\
\hline Feed conversion ratio (FCR) & $0.21 \pm 0.02^{c}$ & $0.23 \pm 0.01^{c}$ & $0.22 \pm 0.05^{c}$ & $0.24 \pm 0.04^{c}$ & $0.05 \pm 0.01^{\mathrm{a}}$ & $0.40 \pm 0.05^{b}$ \\
\hline
\end{tabular}
and BV of rats fed sample diets and reference diet were statistically similar $\left(p^{>} 0.05\right)$, while the CN, FDW, FU, FCR, PER, and AD at 95\% confidence were statistically

Table 3 Growth performance of rats fed diets based on raw and macerated African elemi pulp flours

Values are means and standard deviation $(n=5)$. Means in the same row with different superscript letter are significantly different from one another at $5 \%$ level $\left(p^{<0.05)}\right.$

$N C D$ negative control diet, $R D$ reference diet $\left(\right.$ Nutrend $\left.^{\circledast}\right)$ 
Table 4 In vivo protein quality indices of raw and macerated African elemi pulp-based diets fed to rats

\begin{tabular}{|c|c|c|c|c|c|c|}
\hline \multirow[t]{2}{*}{ Quality index } & \multicolumn{6}{|l|}{ Diets } \\
\hline & $\mathrm{AE}_{0}$ & $\mathrm{AE}_{15}$ & $\mathrm{AE}_{30}$ & $\mathrm{AE}_{45}$ & NCD & $\mathrm{RD}$ \\
\hline Carcass nitrogen (g) (CN) & $7.71 \pm 0.34^{c}$ & $7.39 \pm 0.29^{c}$ & $7.66 \pm 0.51^{c}$ & $8.14 \pm 0.21^{c}$ & $6.01 \pm 0.43^{\mathrm{a}}$ & $10.42 \pm 0.83^{b}$ \\
\hline Fecal nitrogen (g) (FN) & $0.62 \pm 0.16^{\mathrm{b}}$ & $0.82 \pm 0.19^{b}$ & $0.61 \pm 0.08^{b}$ & $0.59 \pm 0.10^{b}$ & $0.36 \pm 0.02^{\mathrm{a}}$ & $0.51 \pm 0.25^{\mathrm{ab}}$ \\
\hline Carcass weight (g) (CW) & $115.09 \pm 20.63^{\mathrm{ab}}$ & $106.42 \pm 11.51^{\mathrm{ab}}$ & $112.43 \pm 38.38^{\mathrm{ab}}$ & $126.21 \pm 29.52^{\mathrm{ab}}$ & $85.55 \pm 4.40^{\mathrm{a}}$ & $142.68 \pm 39.39^{b}$ \\
\hline Fecal dry weight (g) (FDW) & $28.50 \pm 1.38^{b}$ & $28.58 \pm 3.85^{b}$ & $25.67 \pm 3.88^{\mathrm{ab}}$ & $26.83 \pm 5.92^{\mathrm{ab}}$ & $23.33 \pm 0.76^{\mathrm{a}}$ & $20.67 \pm 9.07^{a}$ \\
\hline Protein efficiency ratio (PER) & $2.03 \pm 0.23^{c}$ & $2.16 \pm 0.05^{c}$ & $2.15 \pm 0.45^{\mathrm{c}}$ & $2.28 \pm 0.35^{c}$ & $1.11 \pm 0.24^{\mathrm{a}}$ & $2.67 \pm 0.37^{b}$ \\
\hline Net protein utilization (NPU) & $68.21 \pm 4.89^{b}$ & $69.73 \pm 5.56^{b}$ & $66.29 \pm 18.97^{b}$ & $74.07 \pm 4.83^{\mathrm{a}}$ & - & $80.07 \pm 7.26^{a}$ \\
\hline Apparent digestibility (AD) & $85.46 \pm 3.09^{c}$ & $82.90 \pm 4.51^{\mathrm{c}}$ & $85.71 \pm 2.37^{c}$ & $86.80 \pm 2.18^{c}$ & $69.59 \pm 1.0^{\mathrm{a}}$ & $92.63 \pm 2.57^{b}$ \\
\hline True digestibility (TD) & $94.04 \pm 3.42^{\mathrm{a}}$ & $91.97 \pm 4.63^{\mathrm{a}}$ & $94.15 \pm 2.13^{\mathrm{a}}$ & $94.86 \pm 2.21^{\mathrm{a}}$ & - & $97.82 \pm 2.32^{\mathrm{a}}$ \\
\hline Biological value (BV) & $72.53 \pm 3.68^{\mathrm{a}}$ & $75.86 \pm 9.40^{a}$ & $70.36 \pm 9.52^{a}$ & $78.04 \pm 3.48^{\mathrm{a}}$ & - & $82.17 \pm 5.78^{a}$ \\
\hline
\end{tabular}

Values are means and standard deviation $(n=5)$. Means in the same row with different superscript letter are significantly different from one another at $5 \%$ level $(p<0.05)$

$N C D$ negative control diet, $R D$ reference diet $\left(\right.$ Nutrend $\left.^{\mathrm{R}}\right)$

similar in rats fed sample diets but differed from the reference diet group.

\section{Discussion}

As shown in Tables 3 and 4, the body weight change $(\mathrm{BWC})$, feed intake $(\mathrm{FI})$, nitrogen intake $(\mathrm{NI})$, protein intake $(\mathrm{PI})$, carcass nitrogen $(\mathrm{CN})$, carcass weight $(\mathrm{CW})$, apparent digestibility (AD), and true digestibility (TD) of rats fed diets formulated with African elemi pulp macerated for $15 \mathrm{~min}\left(\mathrm{AE}_{15}\right)$ relative to those fed raw sample diet $\left(\mathrm{AE}_{0}\right)$ were decreased. Extension of the maceration time beyond $15 \mathrm{~min}$ improved the parameters. From the tables, maceration generally improved feed utilization (FU), feed conversion ratio (FCR), protein efficiency ratio (PER) and, except at $\mathrm{AE}_{30}$, net protein utilization and biological value of the rats.

The CN, FU, FCR, PER, and AD of rats fed sample diets, at $95 \%$ confidence were statistically similar but differed from the reference diet group. The reference diet had higher protein-energy ratio than the compounded diets (Table 2). This could explain the improved performance of animals sustained on it over those fed the sample diets (as indicated by $\mathrm{CN}, \mathrm{FU}, \mathrm{FCR}, \mathrm{PER}$, and $\mathrm{AD})$.

In contrast, feed intakes were lower in rats fed the sample diets, especially $\mathrm{AE}_{15}$. This could have precipitated low protein intake, invariably leading to insufficient energy and protein essential for growth (Ukachukwu and Szabo 2003). Anyalogbu and Ezejiofor (2017) observed the presence of phytochemicals like, alkaloids, flavonoids, oxalate, cynogenic glycoside, saponins, and tannins in the raw and processed African elemi pulp. These (albeit below their specific tolerable limits) could, through their specific and synergistic antinutrient activities, negatively influence both feed intake and performance of the animals (Food and Agriculture Organization of the United Nations 2013; Gilani et al. 2012; Ani et al. 2012). Anyalogbu et al. earlier
(2014) reported imbalance in amino acid profile of the plant sample with methionine limiting. Kopeć et al. (2014) indicated that such limiting situation could affect the performance of the animals negatively. Hei and Sarojnalini (2012) stated that protein-rich foods are required, as stipulated by Indian Standard Specifications (IS 8220, 1976), to have protein efficiency ratio of at least 2.0. Notwithstanding being statistically lower than in the reference, the PER were above 2.0 in all the rats sustained on test sample diets given the range $2.03 \pm 0.23$ to $2.28 \pm 0.35$. This is relatively similar to that seen in chicken and beef (2.40) and higher than that of beans (1.70) (Anyalogbu and Onyeike 2018). Rats fed diets formulated with AE, relative to those on $\mathrm{RD}$, have significantly $\left(p^{<} 0.05\right)$ lower AD. Anyalogbu et al. (2017) reported that the plant food on the average contained more saturated than unsaturated fatty acids. This observation could account for the lower digestibility as Apgar et al. earlier (1987) attributed the decreased digestibility of cocoa butter in male Sprague-Dawley rats fed with purified diets containing 5,10 , or $20 \%$ cocoa butter (a predominantly saturated fat) to its fatty acid composition. On the other hand, the FN, CW, TD, and BV were statistically similar $\left(p^{>} 0.05\right)$ in rats fed both samples and reference diets. According to Anyalogbu and Onyeike (2018), apparent (protein) digestibility estimates what is left when protein contained in the feces is subtracted from that contained in the dietary intake, while true digestibility corrects this by eliminating fecal nitrogen compounds that actually originate endogenously, i.e., metabolic fecal nitrogen. Consequently, true digestibility is a unique characteristic of a food that is not affected by the dietary conditions and therefore a better depiction of protein quality than apparent digestibility (Darragh and Hodgkinson 2000). The statistical parity between the FN of the animals on test and reference diets could suggest adequacy of the digestibility of the proteins of the sample diets. 
Biological value (BV) on the other hand measures the fraction of the absorbed dietary protein (nitrogen) that is used by the organism for physiological processes (Srikantia 1981). It therefore quantifies the "usability" of the protein. Volken de Souza et al. (2009) stated that with adequate energy intake, physiological processes could be supported in human by any protein of BV $70 \%$ and above. In this study, the $\mathrm{BV}$ of the rats on both reference and test groups were all above $70 \%$. The statistical similarities between the test and reference groups relative to the TD and BV could be an indication of the similarities in their protein qualities.

\section{Conclusion}

Consequently, the plant food African elemi seed pulp used as masticatories in most parts of Nigeria could be metabolically adjudged rich in high quality protein that is capable of supporting human growth and tissue maintenance.

\section{Abbreviations}

AD: Apparent (protein) digestibility; BV: Biological value; BWC: Body weight change; CN: Carcass nitrogen; CW: Carcass weight; FCR: Feed conversion ratio; FDW: Fecal dry weight; Fl: Feed intake; FN: Fecal nitrogen; FU: Feed utilization; NCD: Negative control diet; NPU: Net protein utilization; PER: Protein efficiency ratio; PI: Protein intake; RD: Reference diet; TD: True digestibility; $A E_{0}, A E_{15}, A E_{30}$, and $A E_{45}$ : African elemi macerated for 15, 30, and 45 min respectively in water $\left(55^{\circ} \mathrm{C}\right)$

\section{Authors' contributions}

The authors are fellow biochemists sharing common interest. AEAA conceived the study, carried out the analyses and calculations, and wrote the first draft. OEN formulated the diets and mapped out the experimental design used. N-APC procured and processed the sample materials used, kept the animals, analyzed the data, and prepared the tables. All the authors revised and edited the first draft and approved the final manuscript.

\section{Funding}

The research was funded by contribution from the authors.

\section{Availability of data and materials}

"Not applicable" for this study

\section{Ethics approval}

The animals (albino rats) used were procured from the Department of Animal Health and Production, Faculty of Veterinary Medicine, University of Nigeria, Nsukka, which has institutional ethical permit for the use of animals in research.

\section{Consent for publication}

"Not applicable" for this study

\section{Competing interests}

The authors declare that they have no competing interests.

\section{Author details}

${ }^{1}$ Department of Biotechnology, School of Biological Science, Federal University of Technology Owerri, Imo State, Owerri, Nigeria. ${ }^{2}$ Department of Biochemistry, Faculty of Chemical Sciences, College of Natural and Applied Sciences, University of Port Harcourt, Port Harcourt, Nigeria. ${ }^{3}$ Department of Biochemistry, Clifford University, Owerrinta, Abia State, Nigeria.
Received: 29 August 2019 Accepted: 21 November 2019

Published online: 07 February 2020

\section{References}

Ani AO, Onweluzo JC, Asogwa IS (2012) Growth performance and haematological indices of rats fed Mucuna seed meal-based diets. Int J Biol Pharm and Allied Sci. 1(11):1625-1636

Anyalogbu EA, Nnoli MC, Ezejiofor TIN, Nweje-Anyalowu PC (2017) Fatty acid composition of two Nigerian masticatories cum traditional snacks: African walnut kernel and African elemi pulp. Intl J Sci Tech Res. 6(7):200-207

Anyalogbu EA, Onyeike EN, Monanu MO (2014) Amino acid profile of heatprocessed Canarium schweinfurthii pulp. J Sci Res Rep. 3(14):1973-1985

Anyalogbu EAA, Ezejiofor TIN (2017) Effect of processing on antinutrients contents of African elemi (Canarium schweinfurthii) and African walnut (Plukenetia conophora) consumed as traditional snacks in Nigeria. Int J Sci and Tech Res. 6(7):383-391

Anyalogbu EAA, Onyeike EN (2018) Biological evaluation of protein quality of processed African walnut seed kernel used as traditional snack in parts of Nigeria. World J Pharm Life Sci. 4(1):85-91

Apgar JL, Shively A, Tarka SM (1987) Digestibility of cocoa butter and corn oil and their influence on fatty acid distribution in rats. J Nutr 117:660-665

Darragh AJ, Hodgkinson SM (2000) Quantifying the digestibility of dietary protein. J Nutr 130(7):1850S-1856S

FAO (2013). Food and Agriculture Organization of the United Nations. Dietary protein quality evaluation in human nutrition. Report of an FAO Expert Consultation, FAO Food and Nutrition Paper 92, Food and Agriculture Organization of the United Nations Rome.

Gilani GS, Xiao CW, Cockell KA (2012) Impact of antinutritional factors in food proteins on the digestibility of protein and the bioavailability of amino acids and on protein quality. Br J Nutr. 108:S315-S332. https://doi.org/10.1017/ S0007114512002371

Hei A, Sarojnalini C (2012) Study of protein quality of some fresh and smokedried hill stream fishes from Manipur, India. New York Sci J 5(11):1-6

IS 8220 (1976): Protein-rich concentrated nutrient supplementary foods, Indian Standards on Nutrition (3.6 Protein Efficiency Ratio), Indian Standards Institution, New Delhi. 1-10. law.resource.org/pub/in/bis/S06/is.8220.1976.pdf.

Kopeć A, Borczak B, Pysz M, Sikora E, Sikora M, Curic D, Novotni D (2014) An addition of sourdough and whey proteins affects the nutritional quality of whole meal wheat bread. Acta Sci Pol Technol Aliment. 13(1):43-54

Millward DJ, Layman DK, Tomé D, Schaafsma G (2008) Protein quality assessment: impact of expanding understanding of protein and amino acid needs for optimal health. Am J Clin Nutr. 87(5):1576S-1581S

Moore DR, Soeters PB (2015) The biological value of protein. Nestle Nutr Inst Workshop Ser 82:39-51. https://doi.org/10.1159/000382000

Pencharz PB, Elango R, Wolfe RR (2016) Recent developments in understanding protein needs - how much and what kind should we eat? Appl Phys Nutr Metab. 41(5):577-580 https://doi.org/10.1139/apnm-2015-0549

Srikantia SG (1981) The use of biological value of a protein in evaluating its quality for human requirements; Joint FAO/WHO/UN Expert Consultation on Energy and protein Requirements. Food and Agriculture Organization of the United Nations, Rome

The United Nations University (1980) Evaluation of protein quality in experimental animals: methods based on changes in body weight. In: Pellett, Young (eds) Nutritional evaluation of protein. United Nations University Press, Tokyo

Ukachukwu SN, Szabo NJ (2003) Effect of processing, additives and vitamin B6 supplementation of Mucuna pruriens var cochinchinensis on broilers. Trop Subtrop Agroecosys. 1:227-237

Volken de Souza CF, Venzke JG, Flores SH, Ayub MAZ (2009) In vivo evaluation of cross-linked milk and wheat proteins mediated by microbial transglutaminase in white Wistar rats. Am J Food Technol. 4:96-107

\section{Publisher's Note}

Springer Nature remains neutral with regard to jurisdictional claims in published maps and institutional affiliations. 